\title{
Similar effects of different mowing frequencies on the conservation value of semi-natural grasslands in Europe
}

\author{
Malin Tälle $^{1}$ (D) Balázs Deák ${ }^{2} \cdot$ Peter Poschlod $^{3} \cdot$ Orsolya Valkó $^{4} \cdot$ Lars Westerberg $^{1}$. \\ Per Milberg ${ }^{1}$
}

Received: 6 September 2017 / Revised: 2 May 2018 / Accepted: 23 May 2018 /

Published online: 29 May 2018

(C) The Author(s) 2018

\begin{abstract}
Both agricultural intensification and abandonment have led to the loss of European semi-natural grasslands. Nature conservation management measures like mowing are essential for preserving the biodiversity of remaining grasslands. However, there are no conclusive results from studies examining effects of different mowing frequencies across Europe. To fill this gap, we evaluated data from European studies comparing mowing frequencies to determine which are the most beneficial from a nature conservation viewpoint. We searched literature for short- and long-term studies comparing the effects of different
\end{abstract}

Communicated by David Hawksworth.

Electronic supplementary material The online version of this article (https://doi.org/10.1007/s1053 1-018-1562-6) contains supplementary material, which is available to authorized users.

Malin Tälle

malin.talle@liu.se

Balázs Deák

balazs.deak@science.unideb.hu

Peter Poschlod

Peter.Poschlod@ur.de

Orsolya Valkó

valko.orsolya@science.unideb.hu

Lars Westerberg

lars.westerberg@liu.se

Per Milberg

permi@ifm.liu.se

1 IFM Biology, Conservation Ecology Group, Linköping University, 58183 Linköping, Sweden

2 Department of Ecology, University of Debrecen, Egyetem tér 1, Debrecen 1032, Hungary

3 Ecology and Conservation Biology, Institute of Plant Sciences, University of Regensburg, 93040 Regensburg, Germany

4 MTA-DE Biodiversity and Ecosystem Services Research Group, Egyetem tér 1, Debrecen 4032, Hungary 
mowing frequencies on outcome measures relevant for biodiversity conservation. We found 29 relevant studies where mowing once per year was compared to higher or lower mowing frequencies. The studies covered various grassland types and organisms. The effects were analysed using response ratios, where mowing once per year, i.e. the traditional mowing frequency in semi-natural grasslands, was compared to mowing every fifth, third or second year and mowing two, three or four times a year. Overall, we found similar effects of the different mowing frequencies on the biodiversity of flora and fauna. More frequent mowing generally had a more positive effect, but differences between frequencies were small. Effects were habitat-specific, differing between site and study conditions. For example, a higher mowing frequency was more beneficial in more productive grasslands. These results suggest that in most European semi-natural grasslands, mowing less frequently is a way of using the limited funds available for management more efficiently while still maintaining grassland conservation values, but e.g. site productivity must be considered when determining a suitable mowing frequency.

Keywords Biomass removal $\cdot$ Cutting $\cdot$ Management intensity $\cdot$ Meadow $\cdot$ Metaanalysis $\cdot$ Species diversity

\section{Introduction}

Semi-natural grasslands in Europe were created and maintained by traditional agricultural practices like grazing and mowing for hay making, which have been used since the Neolithic Age, and the Iron Age or Roman period, respectively (Poschlod et al. 2009). Management of semi-natural grasslands is essential to prevent afforestation as a result of secondary succession (Hansson and Fogelfors 2000; Kahmen et al. 2002; Wahlman and Milberg 2002; Peter et al. 2009). In addition, management (e.g. by mowing) reduces abovegroundbiomass and contributes to nutrient depletion, which promotes the biodiversity of these habitats (Al-Mufti et al. 1977; Oelmann et al. 2009). As a result, semi-natural grasslands often harbour a high number of plant and animal species (e.g. D’Aniello et al. 2011; Chytrý et al. 2015). In fact, some grasslands are among the most species-rich habitats in the manmade landscape of Europe (Poschlod et al. 2009; Wilson et al. 2012). Many of the species present in semi-natural grasslands are confined to this habitat type and are highly dependent on it for their survival. In addition, semi-natural grasslands provide essential ecosystem services like pollination, water regulation and protection from soil erosion (Öckinger and Smith 2007; Bazzoffi 2009; Hönigová et al. 2012). The modernization and intensification of agricultural practices from the 20th century onwards have led to a considerable loss of semi-natural grasslands due to abandonment or conversion of semi-natural grasslands into arable land, conventional fertilized grasslands or forest either through tree planting or natural succession (e.g. Wahlman and Milberg 2002; Firbank 2005). As a result of the high number of specialized grassland species confined to this habitat type and the loss of grassland area, semi-natural grasslands are recognized as being of high conservation value (Crofts and Jefferson 1994).

The maintenance of the remaining traditionally-managed species-rich semi-natural grasslands is becoming increasingly more difficult, for example due to the high cost of sustaining management in marginal areas (Schreiber et al. 2009; Török et al. 2011), especially in the face of the limited funds available for subsidies from the European Union and other sources. Therefore, it is important to optimize the utilization of the available resources 
while still ensuring that the best management method is used to preserve the conservation value of semi-natural grasslands. Previous studies comparing management effects have mostly focused on comparisons of different management methods (e.g., mowing, grazing and burning) with varying results (e.g. Moog et al. 2002; Römermann et al. 2009; Milberg et al. 2014; Tälle et al. 2014; Valkó et al. 2014; Tälle et al. 2015, 2016; Bonari et al. 2017; Gilhaus et al. 2017). However, in addition to the management method, management intensity (i.e. plant biomass removal rate) can also affect grassland biodiversity. Previous studies have revealed a positive effect of a high frequency of biomass removal on grassland biodiversity (e.g. Komac et al. 2014; Tälle et al. 2015). However, many of these studies have focused on the effect of different grazing intensities rather than the effects of different mowing intensities, like the frequency of mowing events. The existing studies mainly compare annual mowing with mowing more or less frequently than once per year (e.g. Bakker et al. 2002; Hájková et al. 2009; Milberg et al. 2017). Results from such studies vary, with evidence in favour of both a higher (e.g. Köhler et al. 2005; Noordjik et al. 2009; Simões et al. 2013; Szépligeti et al. 2018) and a lower (e.g. Jantunen et al. 2007; Everwand et al. 2014; Kőrösi et al. 2014) mowing frequency. However, it is uncertain if the conclusions from single studies are representative for grasslands in general as grassland site conditions may differ substantially (Tälle et al. 2016). Furthermore, most studies only focus on one organism type, span only a few seasons and are of lower quality as they are un-replicated (Tälle et al. 2016). Therefore, the general effects of different mowing frequencies on the biodiversity of plant and animal species in semi-natural grasslands remain unclear, and there are no clear guidelines for choosing the most beneficial mowing frequency.

One way of providing better decision support for managers while overcoming differences between studies and the problem of low quality studies is using meta-analysis to synthesize the results from available studies (Pullin and Knight 2001; Milberg 2014). Studies analysing the effects of mowing frequencies on a larger scale across Europe are lacking (but see Marriott et al. 2004, which focuses on the effect of management extensification in upland areas). Thus, our goal was to determine which mowing frequency is the most effective for preserving the biodiversity of plant and animal species in semi-natural grasslands, using a meta-analysis approach.

\section{Methods}

\section{Literature search strategy}

In October 2015, studies in any language, comparing different mowing frequencies were searched for using the databases Scopus, Biological Sciences, Biological Abstracts and Agricola. The search terms used were mow*, hay*, scythe*, harvest* or cut*; and frequenc*, intensit*, regime*, month*, "every other", "every second", "every third", "mow* time", "mow* date", "harvest* date", "harvest time", "hay* date", "hay* time", "cut* date", "cut* time", season*, or interval*; and grassland*, meadow*, fen*, heath*, wetland*, marsh*, bog* or reed*; and management (where * indicates a wildcard). Only studies performed in Europe were included as we expected European grasslands to have a similar history of formation and agricultural policies compared to grasslands outside of Europe. The exclusion of non-European studies was specified by including the search terms NOT "North America", Australia*, or Chin*, as it was expected that the majority of non-European studies were from these places. Any non-European studies included despite 
the exclusion terms were manually excluded. From the list of articles resulting from the literature search, four highly relevant and well performed studies were chosen as sources of additional articles suitable for inclusion. All articles found in the reference lists of these articles and lists of papers citing these articles, which were not already found in the literature search, were added to the article list.

\section{Inclusion criteria}

First, the articles from the literature search were filtered by title, discarding obviously irrelevant studies. Second, the abstract of the remaining articles was examined and any study comparing different mowing frequencies were kept for the next stage. If the title of an article was ambiguous, or the abstract was missing or ambiguous, the article was kept for the next stage. After the examination of abstracts the full text of the remaining articles were examined in detail.

Studies eligible for inclusion in the meta-analysis had to compare at least two different mowing frequencies. Studies comparing the timing of different mowing events during the same year (e.g., beginning and end of summer) were excluded, as these comparisons were outside of the scope of the present study. Mowing once per year was chosen as the reference treatment (required by the analysis method chosen, see Data synthesis), and therefore had to be used as a treatment in all included studies. Mowing once per year was chosen because most studies included this mowing frequency. In addition, this is the most commonly used mowing frequency in species-rich grasslands (Kapfer 2010; Hejcman et al. 2013). Furthermore, included studies had to examine a relevant outcome for the conservation of semi-natural grasslands. For example, studies on species richness or abundance of desired plant or animal species were included, while studies focused on biomass production or soil nutrients were excluded. In addition, only studies where the desired outcome was clear from a conservation viewpoint, e.g. a higher mean species richness, were included. Studies had to contain data in the form of estimates with a measure of variation (e.g. means and variance). Studies where fertilizers were used during the study period were excluded, as well as studies where grasslands were grazed before or after mowing.

\section{Data extraction}

For the studies that met the inclusion criteria, the sample size, mean and standard deviation (SD) of the studied response variables were extracted (or calculated where a variance measure other than SD was provided). If the sample size or variance measure was not presented or the variance measure used was unclear, we contacted the authors for this information. Of the 17 contacted authors, nine were able to provide additional information. Some studies presented data in figures and in these cases the data were obtained using the program Plot Digitizer (Huwaldt 2014).

In the end, data from studies comparing annual mowing to six different mowing frequencies (mowing every fifth, third and second year and mowing two, three or four times per year) were included in the meta-analyses (Table 1).

The data were compiled in spreadsheets along with information on study characteristics (e.g., grassland type, previous management and the organism group for which data was recorded). The study characteristics were used as explanatory variables in the metaanalysis, making it possible to group and analyse similar studies together. Some classes of explanatory variables were combined to ensure the inclusion of enough studies for 


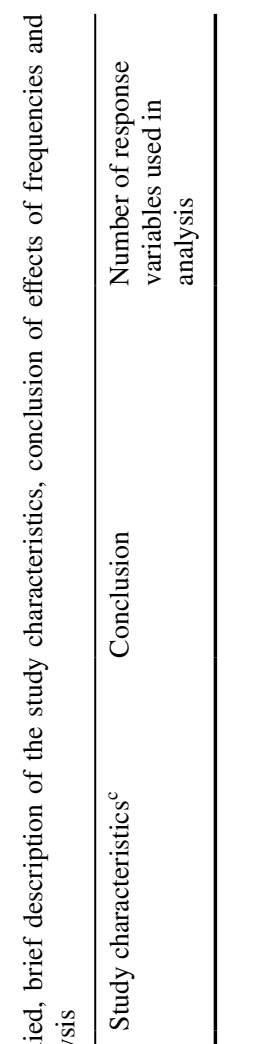

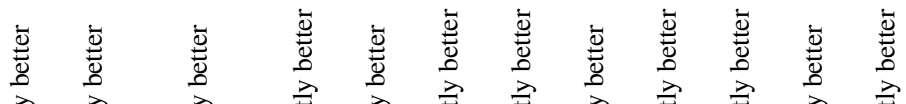

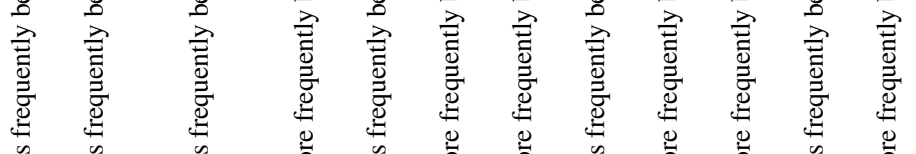

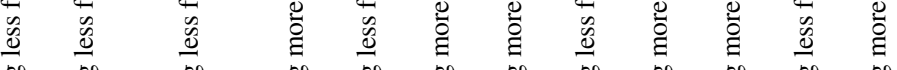

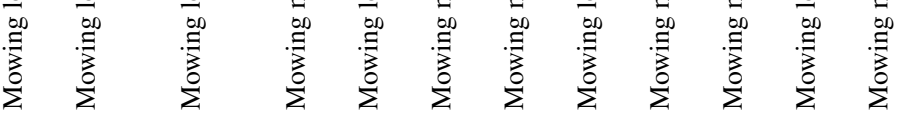

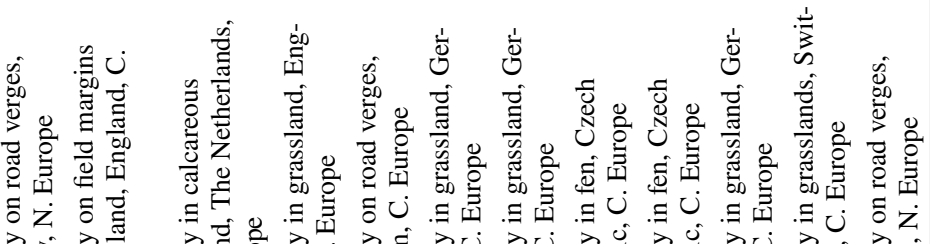

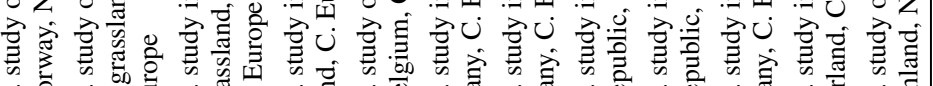

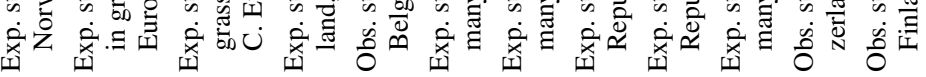

ब

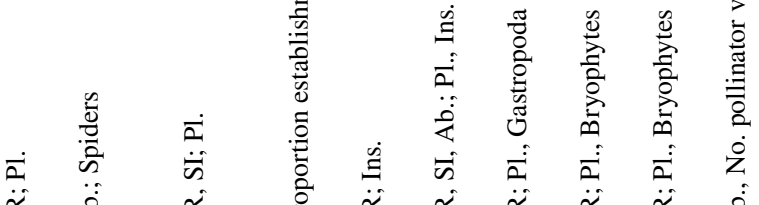

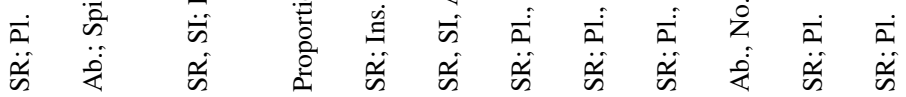

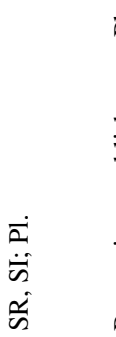

$\dot{a}$

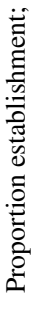

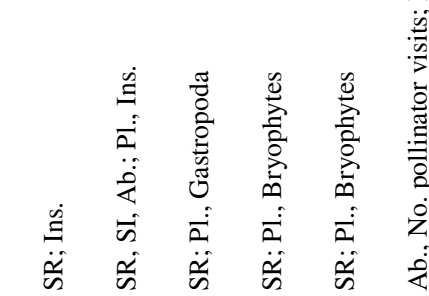

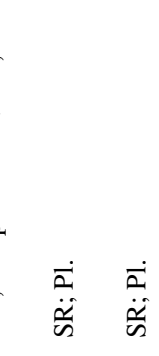

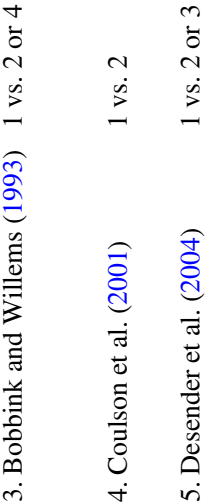

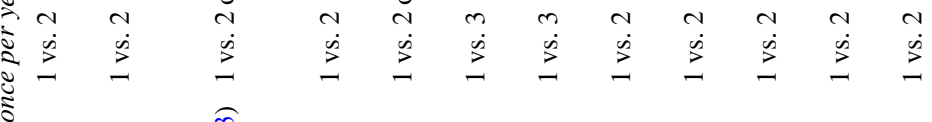
站

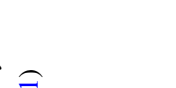

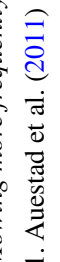

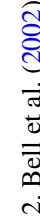

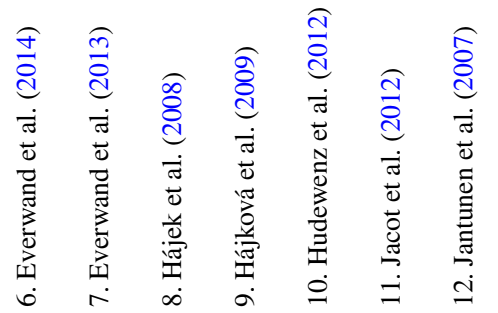




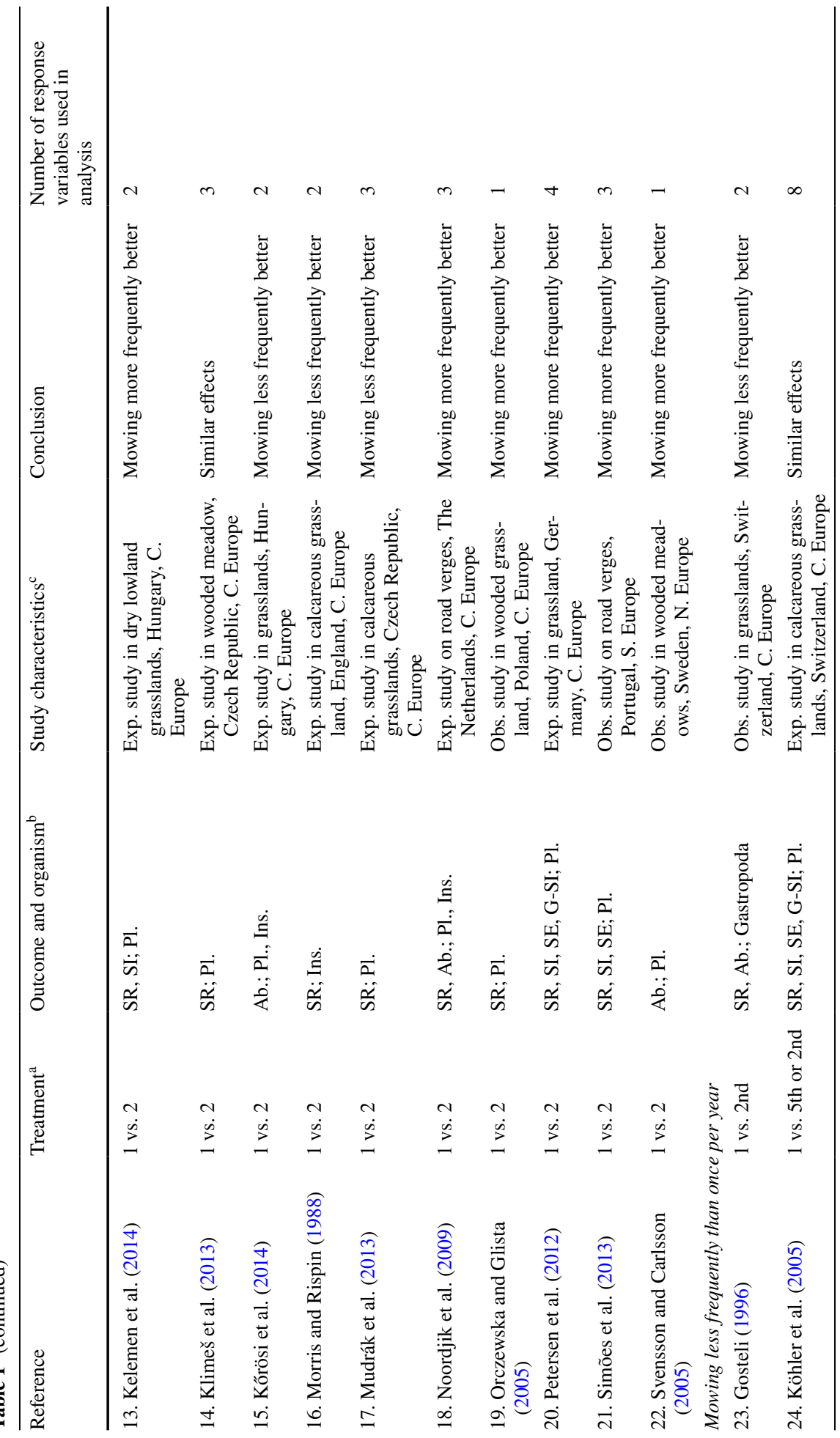




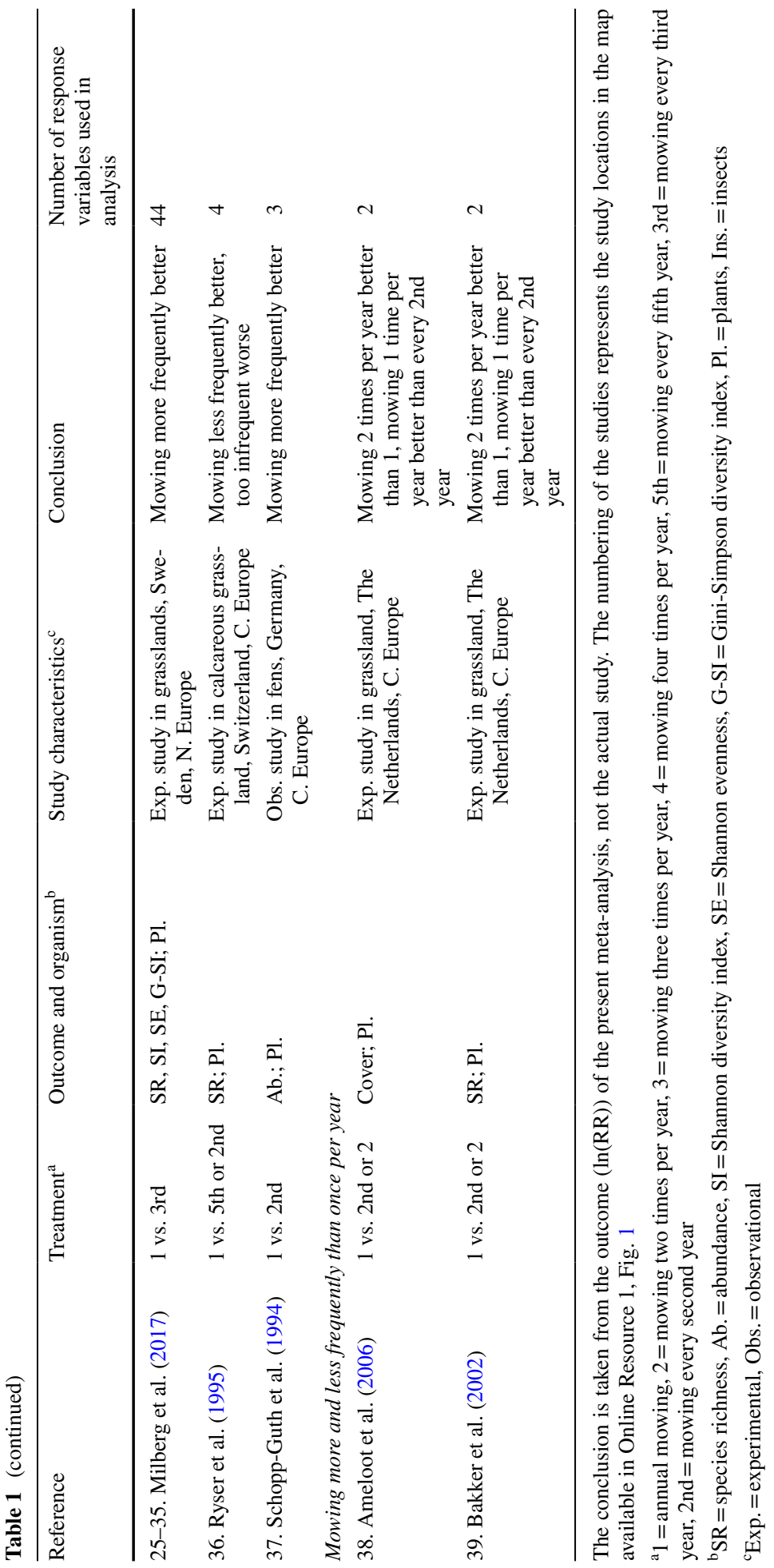


meaningful analyses. For example, the studied countries were combined into the classes South, Central or Northern Europe, and all studies on any type of insect species was combined into the class Insects. Only information on the characteristics explicitly specified in the studies were used. Exceptions to this were the growing season, where information was obtained from Rötzer and Chmielewski (2001), as well as altitude and continentality, which were obtained from Hijmans et al. (2005). The continentality was calculated using

$$
k=(1.7 A / \sin \phi)-20.4
$$

where $k$ is the thermal degree of continentality in percent, $A$ is the difference in temperature between the warmest and coldest months and $\phi$ is the latitude of the study site in question (Gorczýnski 1922). Continentality was mainly used to separate studies on an east-west gradient across Europe (see Online Resource 1, Fig. 1). More information on the explanatory variables used can be found in Table 2. Note that the grassland type was classified as unknown if study sites were termed "grassland", as it was impossible to know whether the use of the term grassland was a strict categorisation or not. The "historical management" was considered being the grassland management prevailing in the area before agricultural intensification, while the "recent management" was the management in the study site immediately prior to the onset of the respective studies, used as a way of identifying if changes in management method occurred at the start of the study.

For those studies that contained data from several years, only data from the most recent inventory was used in the meta-analysis.

\section{Data synthesis}

To compare the effect of different mowing frequencies, the response ratio (RR) was used, i.e. the ratio of the outcome in the alternative mowing treatment to that in the annual mowing. First, the overall weighted mean $\ln (\mathrm{RR})$ was calculated for all studies and mowing frequencies. Second, the analysis of the explanatory variables was performed. The overall weighted mean $\ln (\mathrm{RR})$ within each class of each explanatory variable, and each mowing frequency was calculated. All studies with explanatory variables classified as unknown were removed from the analysis of that specific explanatory variable but were included in other analyses.

In all analyses, $\ln (\mathrm{RR})$ was calculated using random effects models. To avoid bias in $\ln (\mathrm{RR})$ due to small sample sizes, Lajeunesse's (2015) method of calculating $\ln (\mathrm{RR})$ and the variance of $\ln (\mathrm{RR})$ was used

$$
\begin{aligned}
\ln (\mathrm{RR}) & =\ln \left(X_{T} / X_{C}\right)+1 / 2\left[S D_{T}^{2} / N_{T} X_{T}^{2}-S D_{C}^{2} / N_{C} X_{C}^{2}\right] \\
\operatorname{var}(\mathrm{RR}) & =\left[S D_{T}^{2} / N_{T} X_{T}^{2}+S D_{C}^{2} / N_{C} X_{C}^{2}\right]+1 / 2\left[S D_{T}^{4} / N_{T}^{2} X_{T}^{4}+S D_{C}^{4} / N_{C}^{2} X_{C}^{4}\right]
\end{aligned}
$$

where $X$ is the mean, $T$ is the treatment group (the respective mowing frequency), $C$ is the control group (mowing once per year), $S D$ is the standard deviation and $N$ is the sample size. A negative $\ln (\mathrm{RR})$ signifies that mowing once per year is better while a positive $\ln (\mathrm{RR})$ signifies that the other mowing frequency is better. Results can be considered statistically significant (i.e. rejecting the null hypothesis of no difference) if the confidence interval does not overlap zero. Analyses were also run when combining all studies comparing mowing less frequently than once per year or all studies comparing mowing more frequently than once per year. Analyses were made using the software Comprehensive MetaAnalysis 2 (Biostat, Inc 2006). 


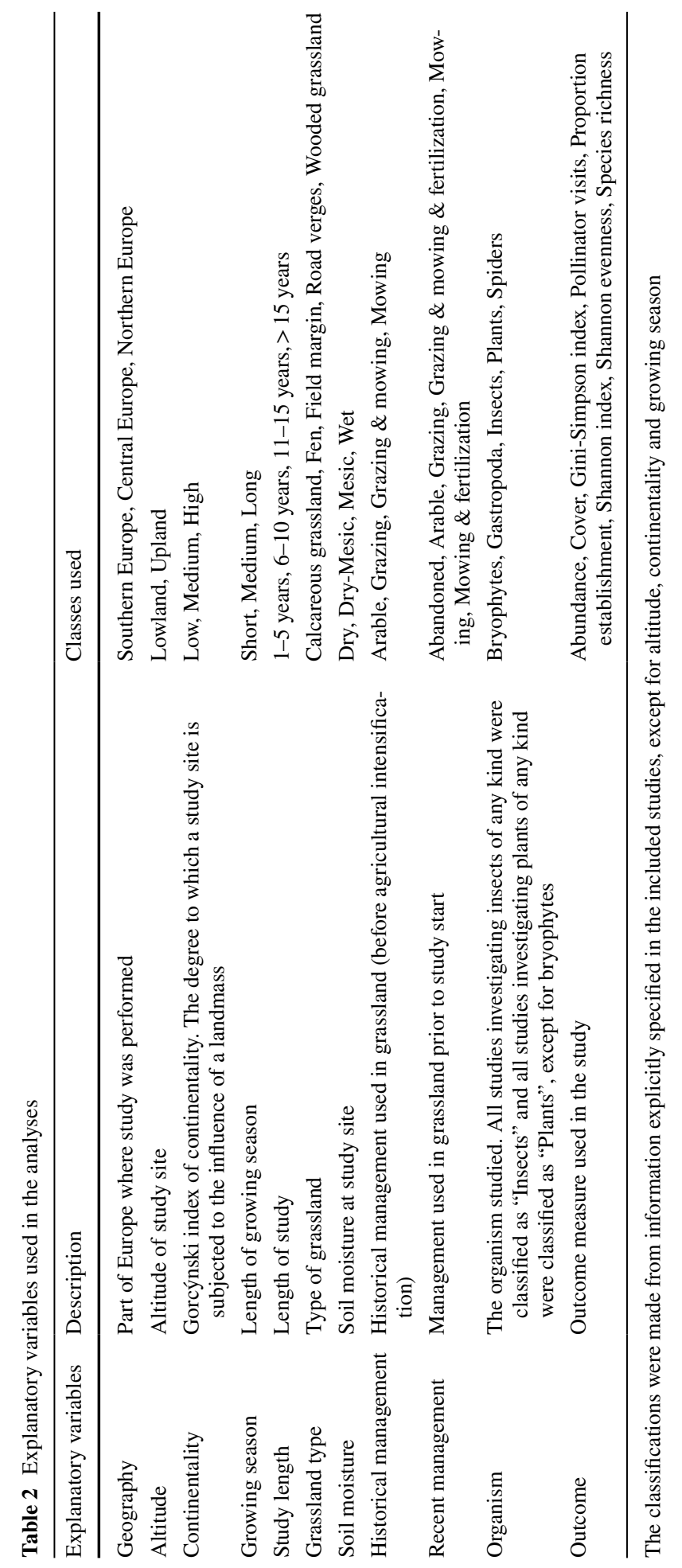


Fig. 1 Overall results comparing the $\ln (\mathrm{RR})$ (with $95 \%$ confidence limits) of different mowing frequencies. Each point is the combined effect of all studies comparing annual mowing with the respective mowing frequency. A negative value signifies a more positive effect of mowing once per year and a positive value signifies a more positive effect of the respective mowing frequency. Grey lines represent the $\ln (\mathrm{RR})$ and the $95 \%$ confidence limits when analysing less frequent mowing than once per year or more frequent mowing than once per year together. Numbers represent the number of response variables for each mowing frequency included in the analysis

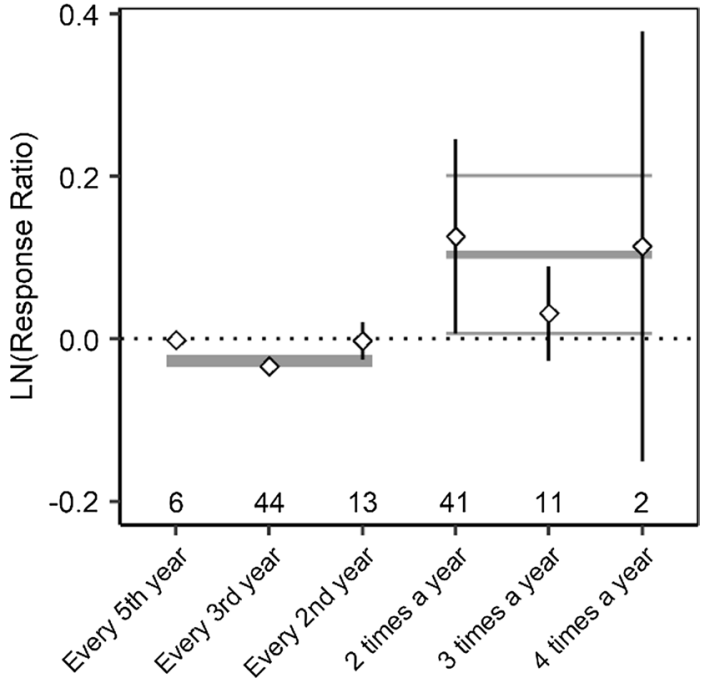

\section{Sensitivity analyses}

To test the robustness of the conclusion of a meta-analysis, sensitivity analyses were performed. The robustness is low if any study has a large impact on the results compared to other studies (Philibert et al. 2012). To adequately test the robustness of the results, three methods were used. First, analyses were run while removing one study at a time to examine the impact of that study. For all studies contributing more than one response variable to an individual analysis, the overall weighted mean $\ln (\mathrm{RR})$ of all response variables from that specific study was used in the analysis instead. Studies with more than one class of the same type of explanatory variable (e.g., if more than one organism was studied or several outcomes were measured) were not included in the sensitivity analysis of that specific explanatory variable. Second, analyses were run while removing one response variable at a time to examine the impact of that response variable. Third, analyses were run with only one response variable per study site (randomly selected when there was more than one response per site), to test if the results were influenced by non-independence between response variables from the same study. If the results were robust, only small differences were expected between the results of the original analyses and the sensitivity analyses, and only modest differences between studies within the analysis of specific explanatory variables.

\section{Publication bias}

Publication bias arises when negative or statistically non-significant results are less likely to be published compared to significant results. This leads to over-estimation of management effects (Dwan et al. 2013). We investigated the presence of publication bias in the studies included in our meta-analysis by means of Egger's regression asymmetry test. A publication bias is considered to exist if $\mathrm{p}<0.1$ (Egger et al. 1997). 


\section{Results}

In total, a list of 2271 articles resulted from the literature search. Of these, 1112 were excluded based on their title and 722 were excluded based on the abstract examination. The full text could not be retrieved for 11 of the 437 remaining articles, leaving 426 articles to be examined in detail. Of these, data from 29 studies could be used, with varying number of response variables per study (117 in total; Table 1). The high number of excluded studies is mainly due to the lack of relevant comparisons and/or data and the use of response variables irrelevant to the present aim, or to the lack of variance information for the response variables.

\section{Overall analysis}

Overall, mowing once per year was marginally more positive than mowing less frequently, while mowing more frequently than once per year had a more positive effect (Fig. 1). More specifically, mowing every second and fifth year had effects similar to mowing once per year, while mowing every third year was marginally worse. For the more frequent mowing regimes, mowing three and four times per year did not significantly differ from mowing once per year while mowing two times per year was significantly, but only slightly, better than mowing once per year $(\ln (R R)=0.125 ;$ Fig. 1).

\section{Analysis of explanatory variables}

The results from the analysis of the different explanatory variables revealed that less frequent mowing generally had an effect quite similar to mowing once per year. More frequent mowing had a similar effect as annual mowing, but in some cases more frequent mowing had a more positive effect (Figs. 2, 3, 4, 5, 6, 7, 8, 9 and 10). Exact values of $\ln (\mathrm{RR})$ for the explanatory variables can be found in Online Resource 1, Tables 1, 2, 3.

For the analysis of geography, the different mowing frequencies had similar effects in Central Europe, mowing more frequently was better in Southern Europe, while results were unclear for Northern Europe (Fig. 2). Effects also differed in the analysis of altitude, as all studied frequencies had similar effects in upland, while in lowland mowing less frequently had similar effects as mowing once per year, while mowing more frequently was more positive (Fig. 3). Effects were similar in study sites of medium continentality. For sites of low continentality mowing more frequently was better, while results were unclear in sites of high continentality (Fig. 4). For the analysis of growing season, effects were moderately clear with a higher mowing frequency being better in areas with longer growing season (Fig. 5).

When analysing the study length, the effects of the mowing frequencies were similar for studies running up to 10 years, but more unclear for studies running longer than that. However, for studies running longer than 15 years, mowing two times per year was significantly better than annual mowing (Fig. 6).

Across the different grassland types, mowing frequencies had quite similar effects. However, for fen grasslands and road verges a higher mowing frequency was slightly better than annual mowing (Fig. 7). Effects were unclear for most of the included soil 


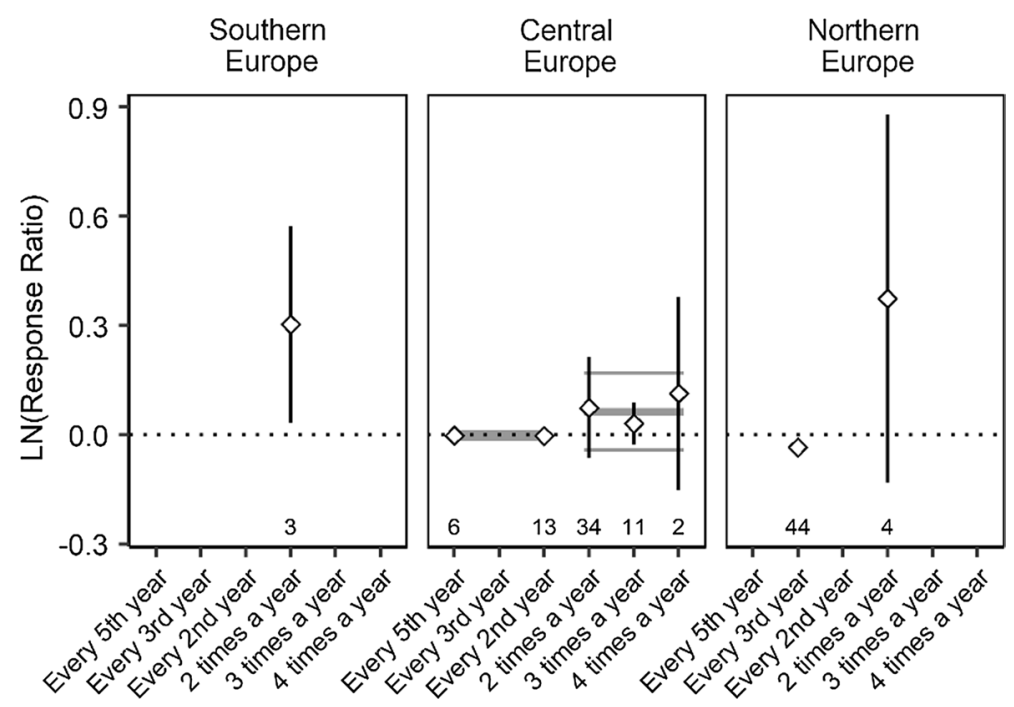

Fig. 2 Geography. The $\ln (\mathrm{RR})$ (with $95 \%$ confidence limits) of different mowing frequencies when grouping studies by geography. For further explanations, see Fig. 1

Fig. 3 Altitude. The $\ln (\mathrm{RR})$ (with $95 \%$ confidence limits) of different mowing frequencies when grouping studies by altitude. For further explanations, see Fig. 1

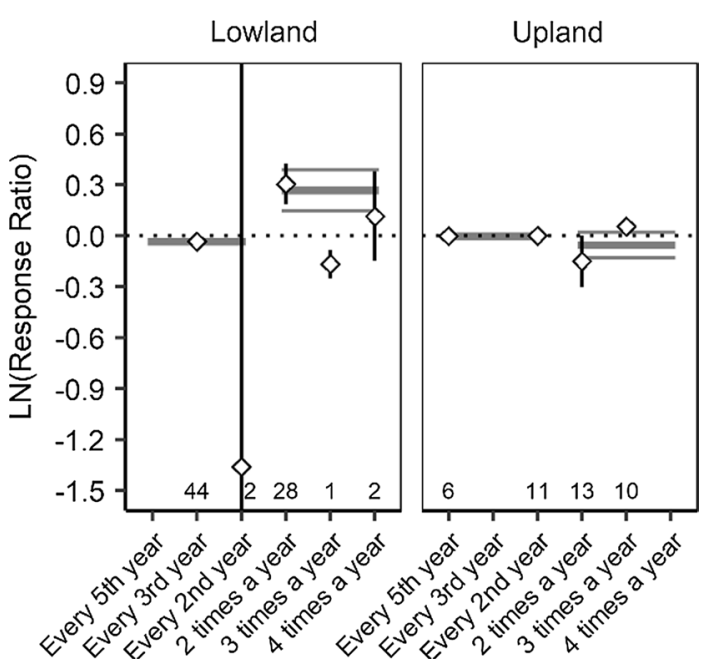

moistures, but for wet grasslands a higher mowing frequency had a slightly more positive effect than annual mowing (Fig. 8).

There were similar effects of different mowing frequencies regardless of the historical or recent management. However, a higher mowing frequency had a more positive effect in grasslands where the previous management intensity was higher (e.g. arable use or previous use of fertilizers; Figs. 9, 10).

Most effects were similar when analysing the organisms studied, but with less frequent mowing being better for Gastropoda and more frequent mowing being slightly better for insects. Depending on the outcome measure used, effects were generally similar between 


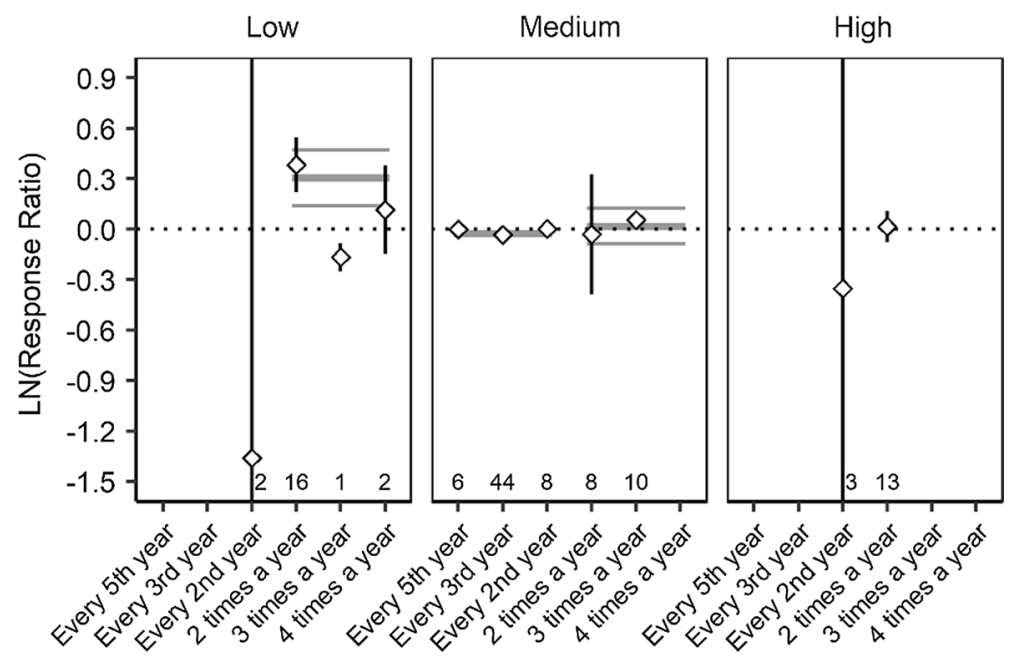

Fig. 4 Continentality. The $\ln (\mathrm{RR})$ (with 95\% confidence limits) of different mowing frequencies when grouping studies by continentality. For further explanations, see Fig. 1

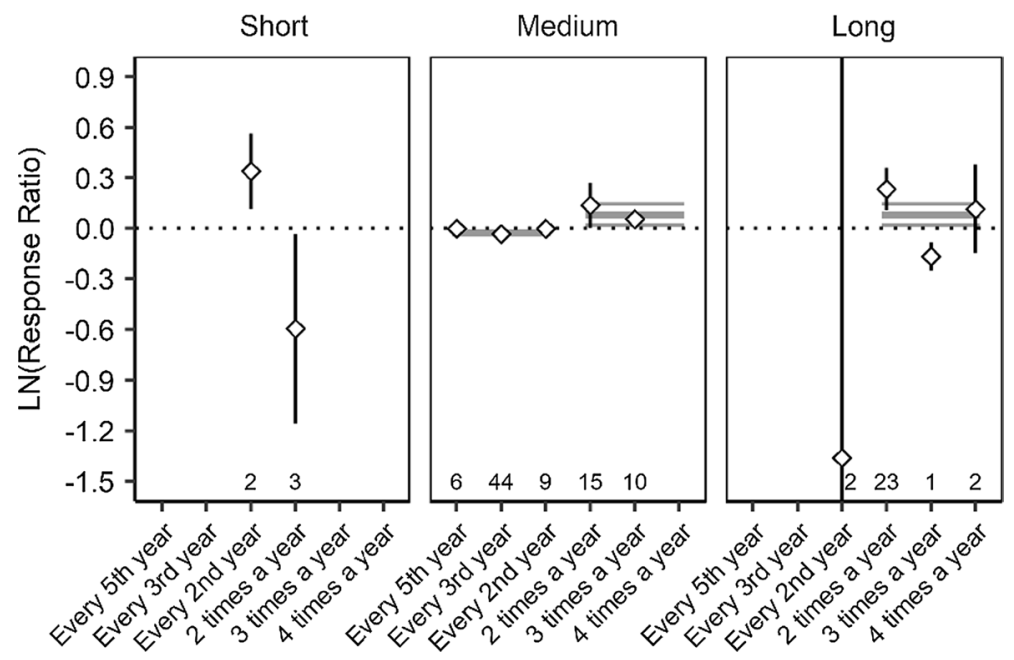

Fig. 5 Length of growing season. The $\ln (\mathrm{RR})$ (with 95\% confidence limits) of different mowing frequencies when grouping studies by the length of the growing season. For further explanations, see Fig. 1

the mowing frequencies except for a slightly more positive effect of more frequent mowing when using abundance and Shannon index (see Online Resource 1, Tables 1, 2, 3).

\section{Sensitivity analyses}

In most cases, the sensitivity analyses of the overall results did not reveal any deviating studies, with effect sizes generally within the confidence interval of the original results. There were 
Fig. 6 Study length. The $\ln (\mathrm{RR})$ (with $95 \%$ confidence limits) of different mowing frequencies when grouping studies by the length of the study. For further explanations, see Fig. 1

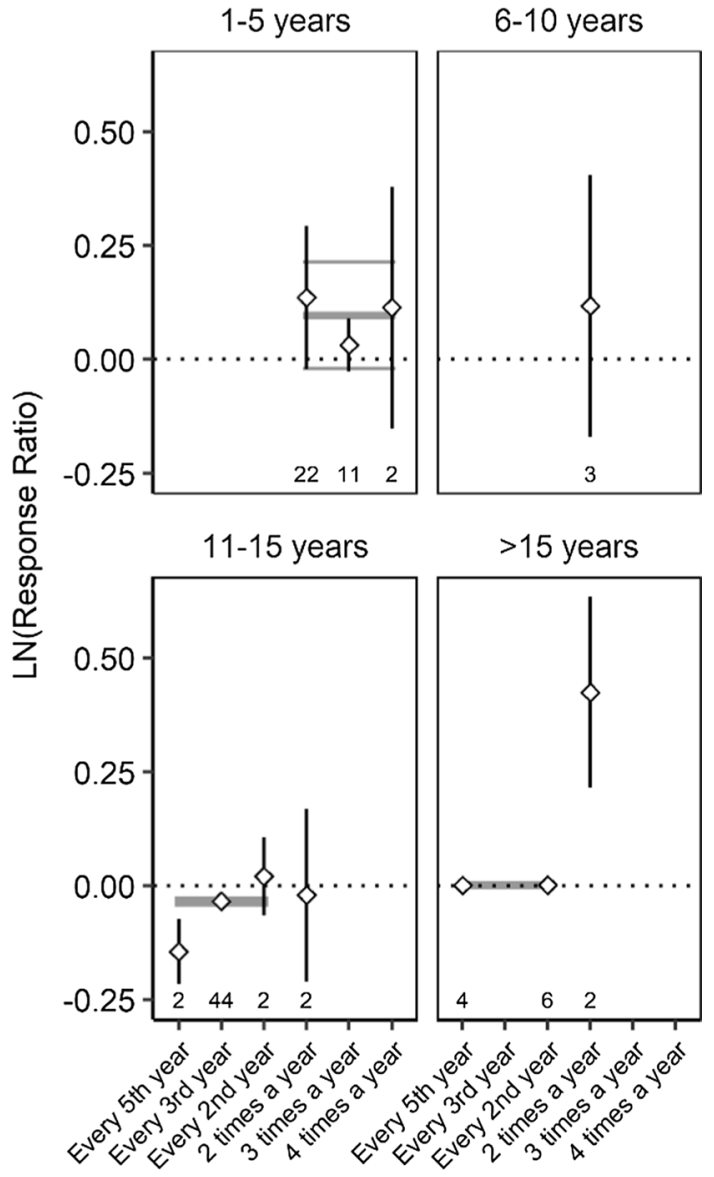

some deviations, most notably analyses with mowing every second year (see Online Resource 1, Figs. 2, 3, 4). For the sensitivity analyses of the explanatory variables, there were also generally small differences compared to the original results, regardless of the type of sensitivity analysis used. For all these analyses, average difference in the effect size of the original results was less than 0.07 , and there were only a few cases where result changed from significant to non-significant or vice versa (see Online Resource 1, Tables 1, 2, 3).

\section{Publication bias}

There was no evidence of publication bias (bias $=1.260, \mathrm{p}=0.152$ ).

\section{Discussion}

The results from our meta-analysis combining results from 29 studies across Europe, comparing six different mowing frequencies with annual mowing, revealed similar effects on grassland conservation values for most mowing frequencies. The results from analyses 
Fig. 7 Grassland type. The $\ln (\mathrm{RR})$ (with $95 \%$ confidence limits) of different mowing frequencies when grouping studies by grassland type. For further explanations, see Fig. 1

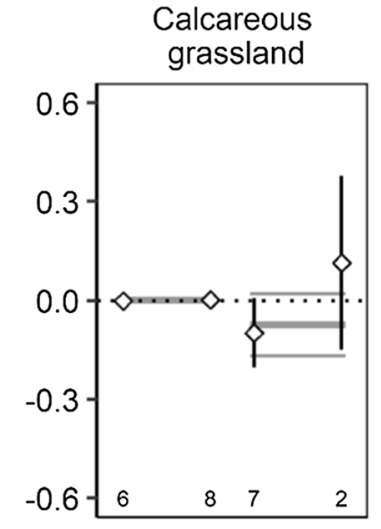

Field margin
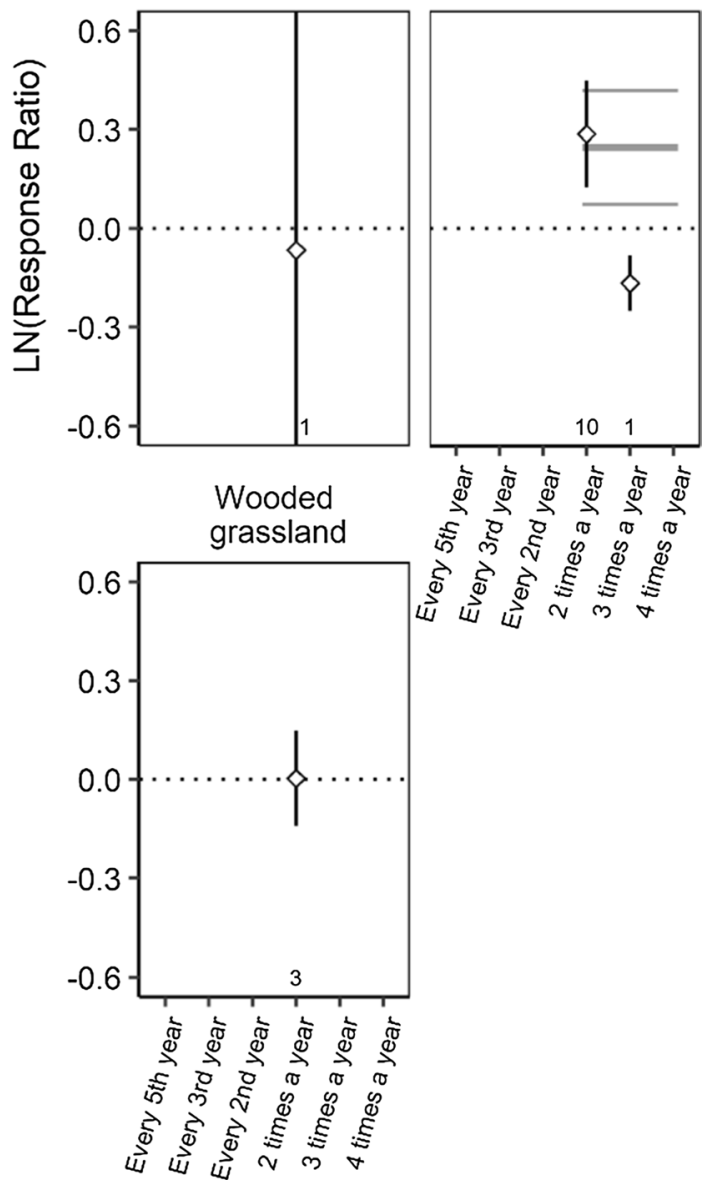
Fig. 8 Soil moisture. The $\ln (\mathrm{RR})$ (with $95 \%$ confidence limits) of different mowing frequencies when grouping studies by soil moisture. For further explanations, see Fig. 1

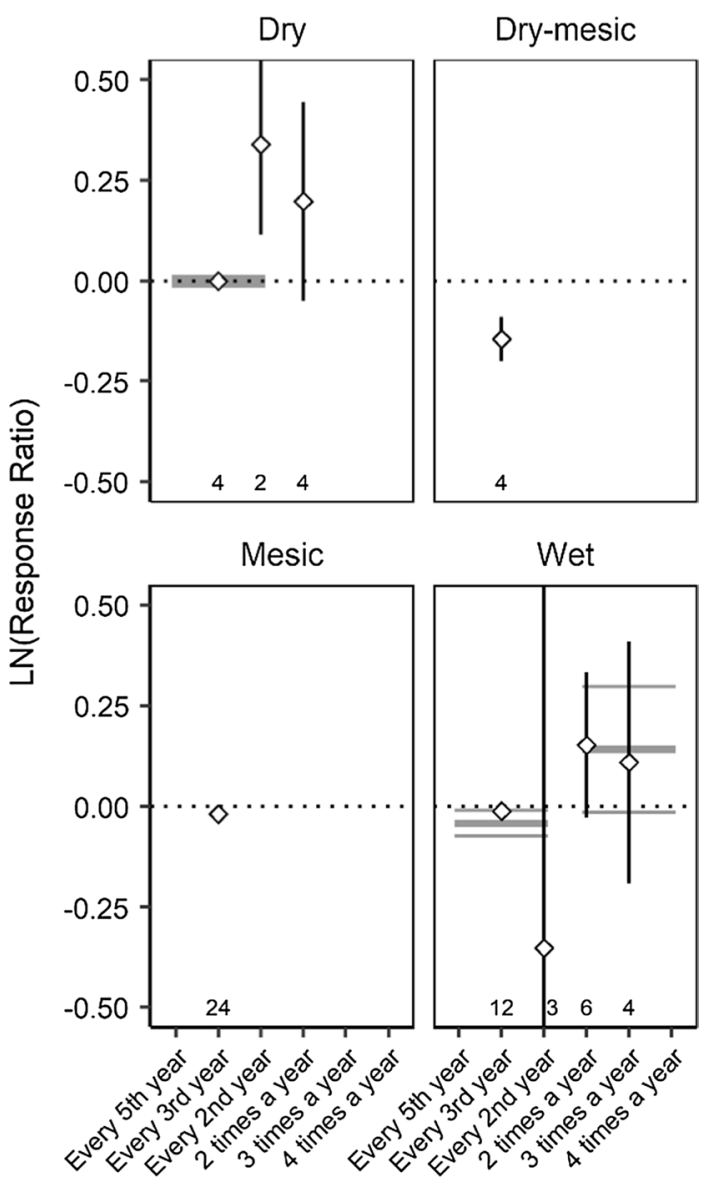

when combining all studies comparing less or more frequent mowing frequencies revealed a more positive effect of more frequent mowing (Fig. 1). Any difference between mowing frequencies found were small however, as the difference in effect sizes was at most 0.126. For context, an $\ln (\mathrm{RR})$ of 0.1 represents the difference between a species richness of two communities consisting of 10 and 11 species. Sensitivity analyses confirmed the robustness of the results (see Online Resource 1). The few cases where results from the sensitivity analyses differed from the original results can be attributed to the fact that for some frequencies and/or explanatory variables only a few response variables were included, which makes these results more subject to sampling error.

The surprisingly small differences in the effects of different mowing frequencies on the conservation value of semi-natural grasslands can be interpreted in different ways. One important factor might be that the fact that any kind of management is actually applied is more important than the intensity of the management itself. For example, Tóth et al. (2018) showed that livestock type is more important than grazing intensity on plant diversity, while Batáry et al. (2010) found no effect of management intensity on the species number and abundance of bees and insect-pollinated plants. Another important point is that both a lower and higher mowing frequency can be expected to have both positive and negative 
Fig. 9 Historical management. The $\ln (\mathrm{RR})$ (with $95 \%$ confidence limits) of different mowing frequencies when grouping studies by the historical management. For further explanations, see Fig. 1

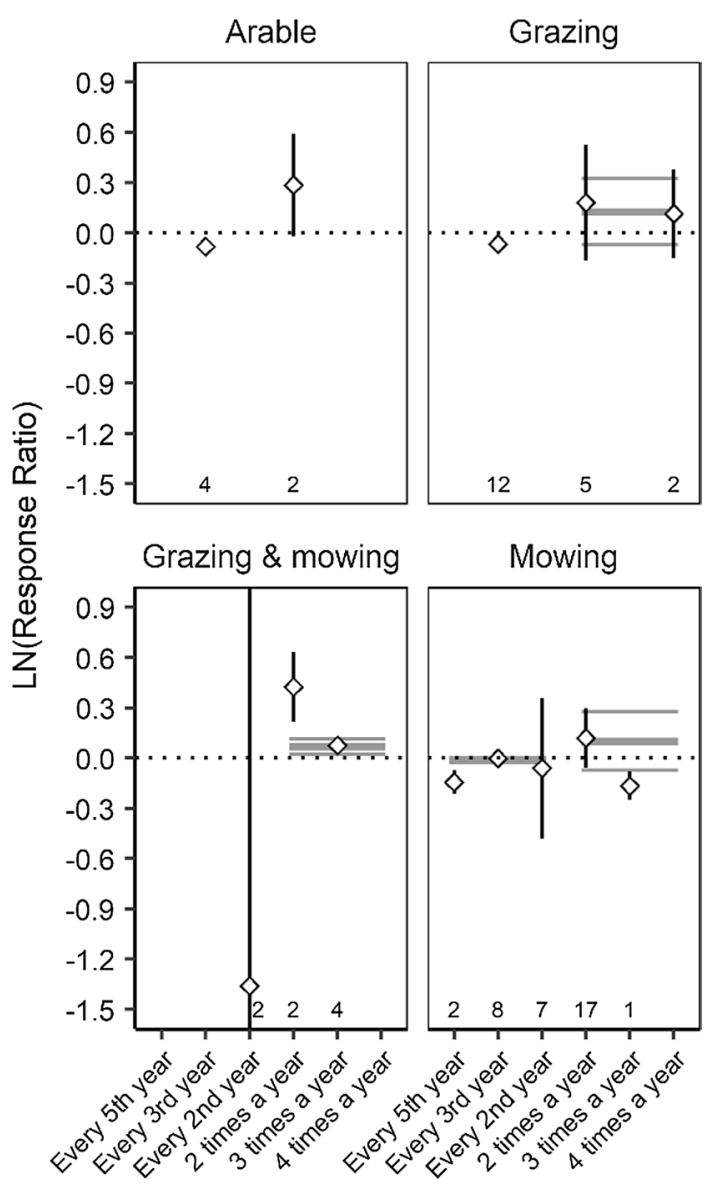

effects at the same time. For less frequent mowing, the amount of litter might increase, which in turn hinders seedling germination and establishment. On the other hand, more frequent mowing might supress the seed set of certain species, thereby threatening their long-term survival (Kahmen and Poschlod 2008; Poschlod et al. 2011; Loydi et al. 2013). Another interpretation is the fact that a lower or higher mowing frequency, which only marginally affects measures like species richness, might still affect the species composition in a grassland. Thus, it is possible that the abundance of each species decreases or the species turn-over increases while the species-richness remains the same, at least on a shorter time-scale, or that grassland specialist species are replaced by generalist ones. If this was the case, however, different results would be expected when comparing species richness and outcomes like Shannon diversity (which takes species abundance into account). We did not find this in the present study, contrary to an experimental study which compared mowing once per year with mowing every third year (Milberg et al. 2017).

The question remains whether species richness is a suitable measure of "conservation value" at all. It would perhaps be more suitable to use the species richness and/or abundance of species of nature conservation interest instead, or to analyse the effects of mowing frequency on the occurrence of indicator species for well-managed semi-natural grasslands (e.g. Karlík and Poschlod 2009; Milberg et al. 2017). One possibly important factor 
Fig. 10 Recent management. The $\ln (\mathrm{RR})$ (with $95 \%$ confidence limits) of different mowing frequencies when grouping studies by the recent management. For further explanations, see Fig. 1

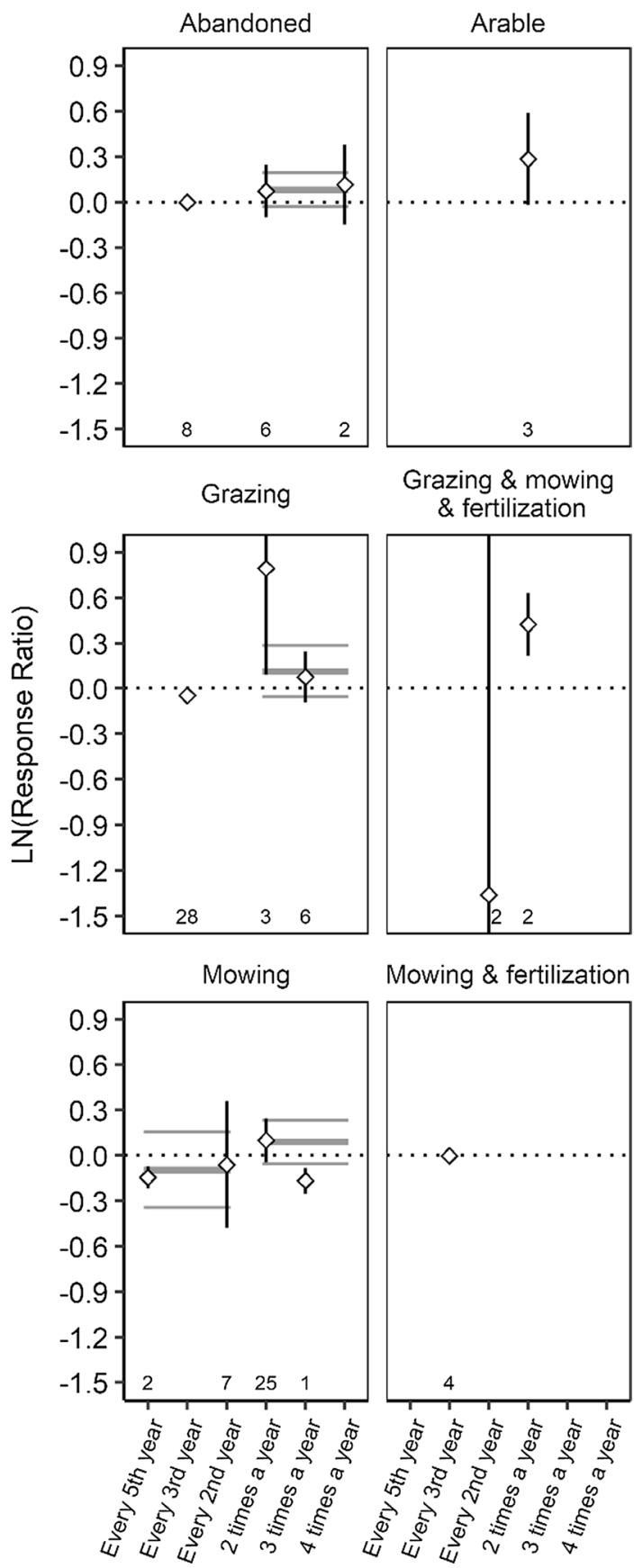

not taken into account in the present study, as this information was not available for most included studies, is the timing of mowing during the year. Effects might differ between early or late mowing (e.g. mowing in early June or late August). Mowing early may have negative effects on species with late seed-setting (Poschlod et al. 2011). Combined with 
more frequent mowing, this can affect species ability to re-sprout, damaging populations of sensitive species (Grime 2001). In fact, a study by Humbert et al. (2012) found a more positive effect of mowing in summer compared to spring- or autumn-mowing for plant species, while a later cut was better for invertebrate species. Further, the most suitable mowing frequency was highly site-specific even after controlling for different explanatory variables. This fact indicates that the mechanisms linking mowing to conservation value are complex.

In many cases, grassland productivity greatly affected which mowing frequency was the most suitable. A higher productivity results in a higher biomass production, potentially resulting in a higher management intensity (mowing frequency or grazing) being necessary to keep grasslands open and facilitate nutrient removal (Al-Mufti et al. 1977; Hautier et al. 2009). Regrettably, it was impossible to directly assess the effects across a productivity gradient as only few studies reported on the biomass production of specific grasslands. However, some of the explanatory variables analysed indirectly indicated the effects of productivity. A higher mowing frequency was better in grasslands with longer growing seasons (Fig. 5), and these grasslands can be expected to produce more biomass overall (Park et al. 2016). An increase in the length of the growing season can be expected along a north-south gradient across Europe (however, not necessarily for dry grasslands) and along an altitudinal gradient from lowlands to mountainous areas. Consequently, a higher mowing frequency was better in Southern Europe. The same could be expected in Central Europe, but there different mowing frequencies had similar effects (Fig. 2). This might be an effect of more arid grasslands in South Eastern Central Europe (e.g. in Hungary) having a lower biomass production despite long growing seasons (Heisler-White et al. 2008). A higher mowing frequency was also better in some lowland grasslands, possibly due to the higher productivity (Fig. 3), as a result of productive grasslands being at the descending part of the biomass-species richness humped-back curve (higher productivity and lower species richness) (Guo 2007; Kelemen et al. 2013). However, another possible reason for this trend is the higher occurrence of invasive species in lowlands, which may require a higher mowing frequency to control (Becker et al. 2005). Productivity is probably also the reason why more wet grasslands and grasslands with higher soil moisture benefitted from a higher mowing frequency (Figs. 7, 8). Wet grasslands are often characterized by higher productivity (Fay et al. 2008) and quicker vegetation dynamics than dry grasslands because of faster succession (Rosenthal 2010). Furthermore, there is often a higher occurrence of clonal species in wet grasslands (e.g. Cyperaceae), which are less sensitive to more frequent mowing or intense grazing (Benot et al. 2011). In some studies, wet grasslands such as fens have been found to be more rapidly overgrown by shrub and tree species and might therefore require a higher mowing frequency (Klimkowska et al. 2010), but other studies have not found this to be the case (Kahmen and Poschlod 2004). A higher mowing frequency was also better in grasslands were the previous management intensity was high (e.g. arable use, application of fertilizers; Figs. 9, 10). This is probably also connected to the higher productivity in these types of grasslands, due to residual nutrients left in the soil or a high-density weed seed bank (Török et al. 2012; Karlík and Poschlod 2014), which are typical for the first period after the conversion of management regime. In addition, during the initial stages of restoration or conversion to management by mowing, a higher mowing frequency might be necessary to support the vegetation development (Sundberg 2012).

Results were unclear for explanatory variables less associated with grassland productivity. The Gorczýnski index of continentality (Gorczýnski 1922) is a measure of how the climate of a site is influenced by a landmass and the remoteness from oceanic air. In the present study, continentality turned out to represent the east-west gradient relatively well, with a higher value of continentality in Eastern European sites (see Online Resource 1, 
Fig. 1). The results revealed a more positive effect of more frequent mowing in study sites of low continentality, similar effects across mowing frequencies in study sites of medium continentality, and mixed effects for high continentality sites (Fig. 4). The unclear effects across the continentality gradient might reflect great differences between sites along this gradient. It should, however, be noted that the gradient in continentality was modest: all sites qualify as a "transitional maritime climate" based on Gorczýnski (1922).

The analysis of study length revealed a similar effect of mowing frequencies for shorterterm studies and less clear effects for longer-term studies (Fig. 6). The reason for the somewhat unclear results could be the more rapid vegetation changes in the first years after introducing a new management method or intensity (Lepš 1987), and the fact that several different factors operate on longer time-scales in addition to management effects (e.g., climate change and atmospheric nitrogen deposition; Walther et al. 2002; Duprè et al. 2010). However, the fact that mowing at a lower frequency did not have a clear negative effect in the long run compared to annual mowing suggests that less frequent mowing can be a viable management option.

There were similar effects across mowing frequencies for both the organism studied and the measurement used. No specific outcomes were expected for these analyses, except for insects and the class Gastropoda for which it can be expected that more frequent mowing has negative effects since previous studies have found positive effects of less intensivemanagement on nectar-seeking insects, grasshoppers (Littlewood et al. 2012; van Klink et al. 2015; Milberg et al. 2016) and the class Gastropoda (Gosteli 1996). In the present study, no such trend was evident for insects while for Gastropoda a lower mowing frequency was better. The fact that there were quite similar effects for the majority of organisms and measurements confirm that there is no clear negative effect of any mowing frequency. However, it is important to note that grassland animal species can be negatively affected by certain mowing techniques (e.g. Humbert et al. 2009).

\section{Management implications}

The results of our analyses revealed surprisingly similar effects of different mowing frequencies with the exception of a clear small, positive effect of more frequent mowing. In addition, the analyses did not reveal any remarkable negative effects of mowing more seldom than once per year. This suggests that the funds available for the management and conservation of the remaining semi-natural grasslands could be used in a more effective way. By application of a management system with mowing of grasslands every second year (for example) the area of managed grasslands could be considerably extended, and nature conservation values could be maintained at a larger spatial scale. However, overly long gaps between cuts may lead to shrub encroachment resulting in a drop in biodiversity over time (Balmer and Erhardt 2000; Milberg et al. 2017). It is important to consider that effectively decreasing the subsidies paid to private farmers (e.g. by paying the same amount less frequently) for each grassland might also decrease the incentive to keep up management despite the decreased management cost per grassland. Nevertheless, in the public or nonprofit sector (e.g., for the management of national parks), decreased management intensity could be beneficial both from a conservation and an economical viewpoint. It is also important to consider that mowing more frequently than once per year had a weak positive effect and might therefore be slightly more beneficial from a conservation viewpoint, if funds are not an issue. Furthermore, the specific site conditions are important when determining a suitable mowing intensity. In sites with high productivity, or sites which have 
previously been managed more intensely, a higher mowing frequency might be necessary. It is also important to consider the conservation aim when determining a suitable mowing frequency as effects on one or a few focal species or taxonomic groups may differ from the general conclusions of the present study.

\section{Compliance with Ethical Standards}

Conflict of interest The authors declare that they have no conflict of interest.

Open Access This article is distributed under the terms of the Creative Commons Attribution 4.0 International License (http://creativecommons.org/licenses/by/4.0/), which permits unrestricted use, distribution, and reproduction in any medium, provided you give appropriate credit to the original author(s) and the source, provide a link to the Creative Commons license, and indicate if changes were made.

\section{References}

Al-Mufti MM, Sydes CL, Furness SB, Grime JP, Band SR (1977) A quantitative analysis of shoot phenology and dominance in herbaceous vegetation. J Ecol 65:759-791

Ameloot E, Verheyen K, Bakker JP, De Vries Y, Hermy M (2006) Long-term dynamics of the hemiparasite Rhinanthus angustifolius and its relationship with vegetation structure. J Veg Sci 5:637-646

Auestad I, Rydgren K, Austad I (2011) Road verges: potential refuges for declining grassland species despite remnant vegetation dynamics. Ann Botanici Fennici 48:289-303

Bakker JP, Elzinga JA, de Vries Y (2002) Effects of long-term cutting in a grassland system: perspectives for restoration of plant communities on nutrient-poor soils. Appl Veg Sci 5:107-120

Balmer O, Erhardt A (2000) Consequencies of succession on extensively grazed grasslands for central European butterfly communities: rethinking conservation practices. Conserv Biol 14:746-757

Batáry P, Báldi A, Sárospataki M, Kohler F, Verhulst J, Knop E, Herzog G, Kleijn D (2010) Effect of conservation management on bees and insect-pollinated grassland plant communities in three European countries. Agric Ecosyst Environ 136:35-39

Bazzoffi P (2009) Soil erosion tolerance and water runoff control: minimum environmental standards. Reg Environ Change 9:169-179

Becker T, Dietz H, Billeter R, Buschmann H, Edwards PJ (2005) Altitudinal distribution of alien plant species in the Swiss Alps. Perspect Plant Ecol, Evol Syst 7:173-183

Bell JR, Johnson PJ, Hambler C, Haughton AJ, Smith H, Feber RE, Tattersall FH, Hart BH, Manley W, Macdonald DW (2002) Manipulating the abundance of Lepthyphantes tenuis (Araneae: Linyphiidae) by field margin management. Agric Ecosyst Environ 93:295-304

Benot ML, Mony C, Merlin A, Marion B, Bouzillé JB, Bonis A (2011) Clonal growth strategies along flooding and grazing gradients in Atlantic coastal meadows. Folia Geobot 46:219-235

Biostat, Inc. (2006) Comprehensive Meta-analysis version 2. Available at www.meta-analysis.com

Bobbink R, Willems JH (1993) Restoration management of abandoned chalk grassland in the Netherlands. Biodiver Conserv 2:616-626

Bonari G, Fajmon K, Malenovský I, Zelený D, Holuša J, Jongepierová I, Kočárek P, Konvička O, Uřičář J, Chytrý M (2017) Management of semi-natural grasslands benefiting both plant and insect diversity: the importance of heterogeneity and tradition. Agric Ecosyst Environ 246:243-252

Chytrý M, Dražil T, Hájek M, Kalníková V, Preislerová Z, Šibík J, Ujházy K, Axmanová I, Bernátová D, Blanár D, Dancák M, Drevojan P, Fajmon K, Galvánek D, Hájková P, Herben T, Hrivnák R, Janecek Š, Janišova M, Jiráská Š, Kliment J, Kochjarová J, Lepš J, Leskovjanská A, Merunková K, Mládek J, Skezák M, Šeffer J, Šefferová V, Škodová I, Uhlírová J, Ujházyová M, Vymazalová M (2015) The most species-rich plant communities in the Czech Republic and Slovakia (with new world records). Preslia 87:217-278

Coulson SJ, Bullock JM, Stevenson MJ, Pywell RF (2001) Colonization of grasslands by sown species: dispersal versus microsite limitation in response to management. J Appl Ecol 38:204-216

Crofts A, Jefferson RG (1994) The lowland grassland management handbook, 2nd edn. English Nature/The Wildlife Trusts, Peterborough 
D’Aniello B, Stanislao I, Bonelli S, Balletto E (2011) Haying and grazing effects on the butterfly communities of two Mediterranean-area grasslands. Biodiver Conserv 20:1731-1744

Desender K, Grootaert P, Dekoninck W, Baert L, De Bakker D, Pauly A, Maelfait J-P (2004) Assessment of nature quality and monitoring of grassland management along the ring motorway around Brussels. Bull de la Soc R Belge d'Entomol 140:126-140

Duprè C, Stevens CJ, Ranke T, Bleekers A, Peppler-Lisbach C, Gowing DJG, Dise NB, Dorland E, Bobbink R, Diekmann M (2010) Changes in species-richness and composition in European acidic grasslands over the past 70 years: the contribution of cumulative atmospheric nitrogen deposition. Glob Chang Biol 16:344-357

Dwan K, Gamble C, Williamson PR, Kirkham JJ (2013) Systematic review if the empirical evidence of study publication bias and outcome reporting bias - an updated review. PLoS ONE 8:e66844

Egger M, Davey-Smith G, Schneider M, Minder C (1997) Bias in meta-analysis detected by a simple graphical test. Br Med J 315:629-634

Everwand G, Scherber C, Tscharntke T (2013) Slug responses to grassland cutting and fertilizer application under plant functional group removal. Acta Oecol 48:62-68

Everwand G, Rösch V, Tscharntke T, Scherber C (2014) Disentangling direct and indirect effects of experimental grassland management and plant functional-group manipulation on plant and leafhopper diversity. BMC Ecol 14:1

Fay PA, Kaufman DM, Nippert JB, Carlisle JD, Harper CW (2008) Changes in grassland ecosystem function due to extreme rainfall events: implications for responses to climate change. Glob Chang Biol 4:1600-1608

Firbank LG (2005) Striking a new balance between agricultural production and biodiversity. Ann Appl Biol 146:163-175

Gilhaus K, Boch S, Fischer M, Hölzel N, Kleinebecker T, Prati D, Rupprecht D, Schmitt B, Klaus VH (2017) Grassland management in Germany: effects on plant diversity and vegetation composition. Tuexenia 37:379-397

Gorczýnski L (1922) The calculation of the degree of continentality. Mon Weather Rev 50:370

Gosteli M (1996) Diversities of snail faunas and ecological relationships between snail communities and vegetation in dry habitats of the northern Swiss Jura (Gastropoda: Prosobranchia et Pulmonata). Malakol Abh 181:107-123

Grime JP (2001) Plant strategies, vegetation processes and ecosystem properties. Wiley, Chichester

Guo Q (2007) The diversity-biomass-productivity relationships in grassland management and restoration. Basic Appl Ecol 8:199-208

Hájek M, Hájková P, Rozbrojová Z (2008) Vliv změny režimu kosení na druhové složení mokřadních luk. (Impact of changes in mowing regime on species composition of wet grasslands). In: Jongepierová I (ed) Louky Bílých Karpat. ZO ČSOP Bílé Karpaty, Veselí nad Moravou, pp 338-345

Hájková P, Hájek M, Kintrová K (2009) How can we effectively restore species richness and natural composition of a Molinia-invaded fen? J Appl Ecol 46:417-425

Hansson M, Fogelfors H (2000) Management of semi-natural grassland; results from a 15-year old experiment in southern Sweden. J Veg Sci 11:31-38

Hautier Y, Niklaus PA, Hector A (2009) Competition for light causes plant biodiversity loss after eutrophication. Science 324:636-638

Heisler-White JL, Knapp AK, Kelly EF (2008) Increasing precipitation event size increases aboveground net primary productivity in a semi-arid grassland. Oecologica 158:129-140

Hejcman M, Hejcmanová P, Pavlů V, Beneš J (2013) Origin and history of grasslands in Central Europe-a review. Grass Forage Sci 68:345-363

Hijmans RJ, Cameron SE, Parra JL, Jones PG, Jarvis A (2005) Very high resolution interpolated climate surfaces for global land areas. Int J Climatol 25:1965-1978

Hönigová I, Vačkář D, Lorencová E, Melichar J, Götzl M, Sonderegger G, Oušková V, Hošek M, Chobot K (2012) Survey on grassland ecosystem services. Report of the European Topic Centre on Biological Diversity. Nature Conservation Agency of the Czech Republic, Prauge. Pp. 78

Hudewenz A, Klein A-M, Scherber C, Stanke L, Tscharntke T, Vogel A, Weigelt A, Weisser WW, Ebeling A (2012) Herbivore and pollinator responses to grassland management intensity along experimental changes in plant species richness. Biol Conserv 150:42-52

Humbert J-Y, Ghazoul J, Walter T (2009) Meadow harvesting techniques and their impacts on field fauna. Agric Ecosyst Environ 130:1-8

Humbert J-Y, Pellet J, Buri P, Arlettaz R (2012) Does delaying the first mowing date benefit biodiversity in meadowland? Environ Evid 1:9

Huwaldt JA (2014) Plot digitizer. Available at http://plotdigitizer.sourceforge.net/. Downloaded 29 February, 2016 
Jacot K, Eggenschwiler L, Beerli C, Bosshard A, Suter M (2012) Significance of different types of meadow edges for plant diversity in the Swiss Alps. Agric Ecosyst Environ 153:75-81

Jantunen J, Saarinen K, Valtonen A, Saarnio S (2007) Flowering and seed production success along roads with different mowing regimes. Appl Veg Sci 10:285-292

Kahmen S, Poschlod P (2004) Plant functional trait responses to grassland succession over 25 years. J Veg Sci 15:21-32

Kahmen S, Poschlod P (2008) Does germination success differ with respect to seed mass and germination season? Experimental testing of plant functional trait responses to grassland management. Ann Bot 101:541-548

Kahmen S, Poschlod P, Schreiber K-F (2002) Conservation management of calcareous grasslands. Changes in plant species composition and response of functional traits during 25 years. Biol Conserv 104:319-328

Kapfer A (2010) Beitrag zur Geschichte des Grünlands Mitteleuropas. Naturschutz und Landschaftsplanung 42:133-140

Karlík P, Poschlod P (2009) History or abiotic filter: which is more important in determining the species composition of calcareous grasslands? Preslia 81:321-340

Karlík P, Poschlod P (2014) Soil seed bank composition reveals the land-use history of calcareous grasslands. Acta Oecol 58:22-34

Kelemen A, Török P, Valkó O, Miglécz T, Tóthmérész B (2013) Mechanisms shaping plant biomass and species richness: plant strategies and litter effect in alkali and loess grasslands. J Veg Sci 24:1195-1203

Kelemen A, Török P, Valkó O, Deák B, Miglécz T, Tóth K, Ölvedi T, Tóthmérész B (2014) Sustaining recovered grasslands is not likely without proper management: vegetation changes and large-scale evidences after cessation of mowing. Biodiver Conserv 23:741-751

Klimeš L, Hájek M, Mudrák O, Dančák M, Preislerová Z, Hájková P, Jongepierová I, Klimešová J (2013) Effects of changes in management on resistance and resilience in three grassland communities. Appl Veg Sci 16:640-649

Klimkowska A, Dzierża P, Kotowsi W, Brzezińska K (2010) Methods of limiting willow shrub re-growth after initial removal on fen meadows. J Nat Conserv 18:12-21

Köhler B, Gigon A, Edwards PJ, Krüsi B, Lagenauer R, Lüscher A, Ryser P (2005) Changes in the species composition and conservation value of limestone grasslands in Northern Switzerland after 22 years of contrasting managements. Perspect Plant Ecol, Evol Syst 7:51-67

Komac B, Domènech M, Fanlo R (2014) Effects of grazing on plant species diversity and pasture quality in subalpine grasslands in the eastern Pyrenees (Andorra): Implications for conservation. J Nat Conserv 22:247-255

Kőrösi Á, Szentirmai I, Batáry P, Kövér S, Örvössy N (2014) Effects of timing and frequency of mowing on the threatened scarce large blue butterfly - A fine-scale experiment. Agric Ecosyst Environ 196:24-33

Lajeunesse MJ (2015) Bias and correction for the log response ratio in ecological meta-analysis. Ecol 96:2056-2063

Lepš J (1987) Vegetation dynamics in an early old field succession: a quantitative approach. Vegetatio 72:95-102

Littlewood NA, Stewart AJA, Woodcock BA (2012) Science into practice: how can fundamental science contribute to better management of grasslands for invertebrates? Insect Conserv Divers 5:1-8

Loydi A, Eckstein RL, Otte A, Donath TW (2013) Effects of litter on seedling establishment in natural and semi-natural grasslands: a meta-analysis. J Ecol 101:454-464

Marriott CA, Fothergill M, Jeangros B, Scotton M, Louault F (2004) Long-term impacts of extensification of grassland management on biodiversity and productivity in upland areas. A review. Agron $24: 447-462$

Milberg P (2014) Evidence-based vegetation management: prospects and challenges. Appl Veg Sci 17:604-608

Milberg P, Akoto B, Bergman K-O, Fogelfors H, Paltto H, Tälle M (2014) Is spring burning a viable management tool for semi-natural grasslands? Appl Veg Sci 17:429-441

Milberg P, Bergman K-O, Cronwall E, Eriksson ÅI, Glimskär A, Islamovic A, Jonason D, Löfqvist Z, Westerberg L (2016) Flower abundance and vegetation height as predictors for nectar-feeding insect occurrence in Swedish semi-natural grasslands. Agric Ecosyst Environ 230:47-54

Milberg P, Tälle M, Fogelfors H, Westerberg L (2017) The biodiversity cost of reducing management intensity in species-rich grasslands: mowing annually vs. every third year. Basic Appl Ecol 22:61-74 
Moog D, Kahmen S, Poschlod P, Schreiber K-F (2002) Comparison of species composition between different grassland managements-25 years fallow experiment of Baden-Württemberg. Appl Veg Sci 5:99-106

Morris MG, Rispin WE (1988) A beetle fauna of Oolitic limestone grassland and the response to conservation management by different cutting regimes. Biol Conserv 43:87-105

Mudrák O, Doležal J, Hájek M, Dančák M, Klimeš L, Klimešová J (2013) Plant seedling in a species-rich meadow: effects of management, vegetation type and functional traits. Appl Veg Sci 16:286-295

Noordjik J, Delille K, Schaffers AP, Sýkora KV (2009) Optimizing grassland management for flowervisiting insects in roadside verges. Biolog Conserv 142:2097-2103

Öckinger E, Smith HG (2007) Semi-natural grasslands as population sources for pollinating insects in agricultural landscapes. J Appl Ecol 44:50-59

Oelmann Y, Broll G, Hölzel N, Kleinebecker T, Vogel A, Schwartze P (2009) Nutrient impoverishment and limitation of productivity after 20 years of conservation management in wet grasslands of north-western Germany. Biolog Conserv 142:2941-2948

Orczewska A, Glista A (2005) Floristic analysis of the two woodland-meadow ecotones differing in orientation of the forest edge. Poli J Ecol 53:365-382

Park T, Ganguly S, Tømmervik H, Euskirchen E, Høgda K-A, Karlsen SR, Brovkin V, Nemani RR, Myneni RB (2016) Changes in growing season duration and productivity of northern vegetation inferred from long-term remote sensing data. Environ Res Lett 11:084001

Peter M, Gigon A, Edwards PJ, Lüscher A (2009) Changes over three decades in the floristic composition of nutrient-poor grasslands in the Swiss Alps. Biodiver Conserv 18:547-567

Petersen U, Wrage N, Köhler L, Leuschner C, Isselstein J (2012) Manipulating the species composition of permanent grasslands - a new approach to biodiversity experiments. Basic Appl Ecol 13:1-9

Philibert A, Loyce C, Makowski D (2012) Assessment of the quality of meta-analysis in agronomy. Agric Ecosyst Environ 148:72-82

Poschlod P, Baumann A, Karlík P (2009) Origin and development of grasslands in central Europe. In: Veen P, Jeffersson R, de Smidt J, van der Straaten J (eds) Grasslands in Europe of high nature value. KNNV Publishing, Zeist, pp 15-25

Poschlod P, Hoffmann J, Bernhardt-Römermann M (2011) Effects of grassland management on the age and reproduction structure of Helianthemum nummularium and Lotus corniculatus populations. Preslia 83:421-435

Pullin AS, Knight TM (2001) Effectiveness in conservation practice: pointers from medicine and public health. Conserv Biol 14:50-54

Römermann C, Bernhardt-Römermann M, Kleyer M, Poschlod P (2009) Substitutes for grazing in seminatural grasslands - do mowing or mulching represent valuable alternatives to maintain vegetation dynamics? J Veg Sci 20:1086-1098

Rosenthal G (2010) Secondary succession in a fallow central European wet grassland. Flora 20:153-160

Rötzer T, Chmielewski F-M (2001) Phenological maps of Europe. Clim Res 18:249-257

Ryser P, Langenauer R, Gigon A (1995) Species richness and vegetation structure in a limestone grassland after 15 years management with six biomass removal regimes. Folia Geobot 30:157-167

Schopp-Guth A, Maas D, Pfadenhauer J (1994) Influnce of management on the seed production and seed bank of calcareous fen species. J Veg Sci 5:569-578

Schreiber K-F, Brauckmann H-J, Broll G, Krebs S, Poschlod P (2009) Artenreiches Grünland in der Kulturlandschaft. 35 Jahre Offenhaltungsversuche Baden-Württemberg. Verlag Regionalkultur, Heidelberg (in German)

Simões MP, Belo AF, Souza C (2013) Effect of mowing regime on diversity of Mediterranean roadside vegetation - implications for management. Poli J Ecol 61:241-255

Sundberg S (2012) Quick target vegetation recovery after restorative shrub removal and mowing in a calcareous fen. Restor Ecol 20:331-338

Svensson BM, Carlsson B̊̊ (2005) How can we protect rare hemiparasitic plants? Early-flowering taxa of Euphrasia and Rhinanthus on the Baltic island of Gotland. Folia Geobot 40:261-272

Szépligeti M, Kőrösi A, Szentirmai I, Házi J, Bartha D, Bartha S (2018) Evaluating alternative mowing regimes for conservation management of Central European mesic meadows: a field experiment. Plant Biosyst 152:90-97

Tälle M, Bergman K-O, Paltto H, Pihlgren A, Svensson R, Westerberg L, Wissman J, Milberg P (2014) Mowing for biodiversity: grass trimmer and knife mower perform equally well. Biodiver Conserv 23:3073-3089 
Tälle M, Fogelfors H, Westerberg L, Milberg P (2015) The conservation benefit of mowing vs. grazing for management of species-rich grasslands: a multi-site, multi-year field experiment. Nordic J Bot 33:761-768

Tälle M, Deák B, Poschlod P, Valkó O, Westerberg L, Milberg P (2016) Grazing vs. mowing: a metaanalysis of biodiversity benefits for grasslands management. Agric Ecosyst Environ 222:200-212

Török P, Vida E, Deák B, Lengyel S, Tóthmérész B (2011) Grassland restoration on former croplands in Europe: an assessment of applicability of techniques and costs. Biodiver Conserv 20:2311-2332

Török P, Miglécz T, Valkó O, Kelemen A, Deák B, Lengyel S, Tóthmérész B (2012) Recovery of native grass biodiversity by sowing on former croplands: is weed suppression a feasible goal for grassland restoration? J Nat Conserv 20:41-48

Tóth E, Deák B, Valkó O, Kelemen A, Miglécz T, Tóthmérész B, Török P (2018) Livestock type is more crucial than grazing intensity: traditional cattle and sheep grazing in short-grass steppes. Land Degrad Dev 29:231-239

Valkó O, Török P, Deák B, Tóthmérész B (2014) Prospects and limitations of prescribed burning as a management tool in European grasslands. Basic Appl Ecol 15:26-33

van Klink R, van der Plas F, van Noordwijk CGE, Wallis de Vries MF, Olff H (2015) Effects of large herbivores on grassland arthropod diversity. Biol Rev 90:347-366

Wahlman H, Milberg P (2002) Management of semi-natural grassland vegetation: evaluation of a long-term experiment in southern Sweden. Ann Botanici Fennici 39:159-166

Walther G-R, Post E, Convey P, Menzel A, Parmesan C, Beebee TJC, Fromentin L-M, Hoegh-Guldberg O, Bairlein F (2002) Ecological responses to recent climate change. Nat 416:389-395

Wilson JB, Peet RK, Dengler J, Pärtel M (2012) Plant species richness: the world records. J Veg Sci 23:796-802 